\title{
Connecting formal and informal spaces: a long-term and multi-level view of Medellín's Metrocable
}

\author{
Madeleine Galvin *iD and Anne Maassen
}

\author{
* Correspondence: madeleine. \\ galvin@wri.org \\ WRI Ross Center for Sustainable \\ Cities, 10 G Street NE, Suite \#800, \\ Washington, D.C. 20002, USA
}

\begin{abstract}
The inauguration of Medellín, Colombia's aerial cable car in 2004, is widely seen as a key turning point in reversing the city's historical reputation for drug and gangrelated crimes towards greater inclusiveness and public safety. Analyses of Medellín's transformation have tended to focus on establishing the immediate positive outcomes achieved from the cable car and assessing persistent inequality and the fragile balance between enfranchisement and top-down institutional control. In this paper, we take these interpretations of Medellín's transformation as our starting point and propose that a lasting legacy is to be found in the way the city plans for and works in disinvested areas. Our focus is on examining the elements that have made transformation possible in Medellín. We begin by exploring a set of framing conditions during the period of 1991 to 2000 ('Before Line K') and then outline the implementation of Metrocable and its shorter-term outcomes ('Executing Line K'), before finally reflecting on the wider transformative impacts of this experience ('Beyond Line K'). As key takeaways, we highlight the role of national policy, municipal finance, and community engagement in bringing a highly informal space into the reach of public institutions, thus providing insights for urban decisionmakers looking to do the same.

Keywords: Metrocable, Medellín, Informality, Municipal finance, Community engagement, Transparency
\end{abstract}

\section{Policy and practice recommendations}

1. Engage with local stakeholders to gain insight as to how and where to target spatial interventions.

2. Support multi-sectoral coalitions through national mandates to ensure greater community representation and transparency in project design and execution.

3. Capitalize on institutional learning through inter-agency partnerships for more strategically designed public projects that appeal to the local context.

4. Diversify public revenue sources and commit to project deadlines to demonstrate state capacity and dedication through meeting public milestones.

(c) The Author(s). 2020 Open Access This article is licensed under a Creative Commons Attribution 4.0 International License, which permits use, sharing, adaptation, distribution and reproduction in any medium or format, as long as you give appropriate credit to the original author(s) and the source, provide a link to the Creative Commons licence, and indicate if changes were made. The images or other third party material in this article are included in the article's Creative Commons licence, unless indicated otherwise in a credit line to the material. If material is not included in the article's Creative Commons licence and your intended use is not permitted by statutory regulation or exceeds the permitted use, you will need to obtain permission directly from the copyright holder. To view a copy of this licence, visit http://creativecommons.org/licenses/by/4.0/. 


\section{Introduction}

Medellín's Metrocable, the world's first urban mass transit application of cable car technology, has been the subject of great interest over the past decade, mainly because of the positive outcomes it is thought to have had on the city. Much of the academic writing on Metrocable focuses on these sectoral outcomes in isolation, such as the reduction in the homicide and poverty rates around station areas (Bocarejo et al. 2014), which were shown to outpace a general downward trend across the city (Cerda et al. 2012). Others examine the process of transformation in Medellín but do so through a health and wellbeing perspective (Corburn et al. 2019). In this article, we take as our starting point that it is the collective effect of the various changes that occurred in the city's physical environment, institutional and financial structures, and behaviors and mental models that can be understood as an 'urban transformation' (Maassen and Galvin 2019). However, it is also important to note that critical commentary describes Metrocable's outcomes as promoting neoliberal policies (Franz 2017) and maintaining unequal societal structures (Sotomayor 2015).

Accepting the validity of both arguments as indicating that urban transformation is an imperfect and contested process, we here focus on the experience of executing Metrocable (the 'how') and achieving its immediate outcomes, to understand how this experience translated into a long-term, multi-level process of planning for large-scale projects in formerly disinvested areas of Medellín. Our focus is on examining the elements that have made transformation possible in Medellín in a long-term perspective. We begin by exploring a set of framing conditions during the period of 1991 to 2000 ('Before Line $\mathrm{K}^{\prime}$ ) and then outline the implementation of Metrocable and its shorterterm outcomes ('Executing Line $\mathrm{K}^{\prime}$ ), before finally reflecting on the wider transformative impacts of this experience ('Beyond Line $\left.\mathrm{K}^{\prime}\right)$.

\section{Before Line $\mathrm{K}$}

Medellín is a city of roughly 2.5 million inhabitants located in the Aburra Valley region of Colombia. The city is the second largest in the nation, and has traditionally had a very well-established upper class, due to its beginnings as a gold mining town and its later transition into an industrial hub during the twentieth century (Ferrari et al. 2018). Decentralization in Colombia began in the 1980s, which, coupled with global economic decline, farmland expropriation, and mass rural to urban migration, precipitated a rise in violent conflict in Medellín. Efforts by the state to dismantle the drug cartel behind the violence were unsuccessful and led to increased crime in the city's poorest neighborhoods. By 1991, the homicide rate in Medellín peaked at 381 murders per 100,000 people (Moncada 2016a, 2016b), attracting international attention, damaging the business environment and prompting the national government to intervene with a constitutional reform that further devolved administrative power to local entities in an effort to curb the violence. From this reform, Medellín acquired new fiscal and administrative powers that enabled it to set and achieve actionable goals for its constituents (Sotomayor 2015).

The constitutional reform of 1991 led to a significant restructuring of Medellín's institutions. In an effort to curb the increasing homicide rate, the national government mandated the creation of the Presidential Council for Medellín, a collective of local and national officials, the private sector, community organizations, and academics 
(Restreppo-Miethe 2016) that brought the municipality closer to its community-based organizations (CBOs) to develop a strategy to combat the city's rampant violence. It created a more direct pathway for city-to-citizen communication by mandating that each mayoral term be accompanied by a Municipal Development Plan and vetted by civil society organizations (Gomez et al. 2009). Additionally, it gave the municipality greater resources and freedom to enact specific public works projects by devolving increased central government revenues to municipalities and instituting tax reforms (Salazar 2013). This process brought together diverse stakeholders around reshaping the development narrative of Medellín through the improvement of its most at-risk areas (Restreppo-Miethe 2016).

The Council identified the city's extreme violence as a byproduct of deep socioeconomic inequalities and developed its strategy around the establishment and strengthening of key government institutions and services in conflict-ridden areas (Moncada 2016a, 2016b). In the 1996 Strategic Plan, the impoverished hillside neighborhoods were identified as a hotspot where above-average homicide rates coincided with socioeconomic deprivation and spatial isolation from the rest of the city (IDB 2011). Partnerships with CBOs gave municipal officials insight on how and where to target their spatial interventions in these areas, while the business community funded research centers to monitor municipal actions and promote transparency (Restreppo-Miethe 2016). These efforts created a network of organizations to ensure government accountability and increase the connectivity between citizens and the state. It also began to draw diverse stakeholders into the city decision-making process as more people realized their stake in the interconnectedness of Medellín. It was in this context that cross-sectoral projects centered around investing in deprived areas were prioritized.

A number of large-scale infrastructure projects during the 1990s served as critical opportunities for the municipality to learn how to best harness and structure its new fiscal and administrative powers to work in informal areas. The construction of Metro Line A demonstrated the significance of stable and local funding sources, as well as local capacity for successful project execution, as the project, originally set to open in the 1980s, was delayed until 1994 due to issues with foreign finance and external contracting. While the project was not considered successful from a management perspective, it remained popular, due to the extensive community outreach and participatory strategies that Metro de Medellín, the publicly-owned transit agency, used to increase acceptance of the development (Maclean 2015).

The importance of community engagement was reinforced during the PRIMED project in 1996, which attempted a large-scale upgrade of numerous slum communities, and used engagement in a passive, consultative manner that was ultimately unsuccessful and led to the project being phased out in 2000 (Bahl 2012). Lessons from the PRIMED project later formed the social participation core of the city's urban development strategy (Ferrari et al. 2018).

In 1998, an initial proposal from Metro de Medellín was presented that used an aerial cable car as a means of connecting the Santo Domingo neighborhood to the city center. Santo Domingo was the first of several hillside slums that would be connected to the wider city to overcome disconnection from state services and institutions. The use of cable cars for mass transit in an urban setting was an entirely new way of using a technology that had been used mostly in low usage, tourist destinations. 
This transit innovation bypassed the difficult terrain and inadequate road network and reduced the nearly two hour commute to the city center, where most residents had to travel to gain access to jobs and services (Brand and Davila 2011). With the eventual goal of boosting social cohesion and service provision in what was considered an informal area, Metro de Medellín and the municipality refined the strategy of using infrastructure as a means of community development (Sotomayor 2015), and created a project plan that capitalized on both entities' experiences with community engagement, partnerships, and the strategic deployment of municipal finances.

\section{Executing Line $\mathrm{K}$}

With the mayoral election of Luis Perez in 2000, the Metrocable project gained political momentum. The first financial and technical studies for Metrocable provided an initial assessment of potential entry points for outreach. Teams from Metro de Medellín drew on their community engagement experience with Metro Line A to map out the social fabric of neighborhoods. Shortly after Metro de Medellín and the municipality introduced the cable car in Medellín's Development Plan for 2001-2003, project teams set up neighborhood committees to enhance communication (Restreppo and Orsini 2015). These committees helped mitigate initial distrust and violence and brought local stakeholders and municipal officials together to discuss mutual goals for the community. ${ }^{1}$

Metro de Medellín and the Municipality of Medellín signed a cost-sharing agreement in 2002 committing to contribute 45 and 55\%, respectively, to the project budget. In 2004, the new mayor, Sergio Fajardo, began using 'social urbanism,' a policy focused on improving disinvested areas through the establishment of critical services and infrastructure (Restreppo and Orsini 2015), as a comprehensive development strategy and created the Integral Urban Projects (PUIs), which combined physical upgrades, such as Metrocable, with investments in social capital. The city's ownership of key enterprises, such as Empresas Publicas de Medellín, the main energy company, which puts 30\% of its revenue towards social betterment projects (Bateman et al. 2011), and strong tax base allowed for Metrocable to be built without gaps in construction, thereby bolstering the sentiment of state capacity and dedication. The first PUI directed substantial public investment to social infrastructure such as schools, affordable housing, business development centers, and the improvement of public spaces. In the same year, the city adopted a management and budgeting system to assist with project planning and execution. This system strengthened the municipality's connection to local communities by extending opportunities to participate in local projects (Gomez et al. 2009), furthering both the symbolic and real increase in municipal accountability.

Shortly after the inauguration of Line $\mathrm{K}$, several positive outcomes were observed (noted in Table 1), including a $50 \%$ increase in land values, a $65 \%$ reduction in commuting costs and time for over 150,000 neighborhood residents, and an investment in thousands of square meters of public space around cable car stations (Ramirez 2011).

\section{Beyond Line K}

While the immediate outcomes are important to note, the transformative impacts of Metrocable and its associated public investments are rooted in residents' perception of

${ }^{1}$ Interview with local community organizer, Santo Domingo neighborhood. 
Table 1 Outcomes associated with Metrocable after project implementation (Source: Maassen and Galvin 2019)

\begin{tabular}{|c|c|c|c|c|}
\hline Physical environment & $\begin{array}{l}\text { Institutional structures } \\
\text { and routines }\end{array}$ & Financial money flows & $\begin{array}{l}\text { Behaviors and } \\
\text { daily life }\end{array}$ & $\begin{array}{l}\text { Perceptions and } \\
\text { mental models }\end{array}$ \\
\hline $\begin{array}{l}\text { - Three stops of Line K } \\
\text { serving low income } \\
\text { population built } \\
\text { - Additional } 40,000 \\
\text { square meters of } \\
\text { public spaces and } \\
\text { recreational facilities } \\
\text { constructed } \\
\text { - Atmospheric } \\
\text { emissions from } 1.7 \\
\text { million gallons of } \\
\text { diesel fuel avoided } \\
\text { (per year) } \\
\text { - Cities in Colombia } \\
\text { and Latin America } \\
\text { replicated } \\
\text { Metrocable } \\
\text { Construction caused } \\
\text { a small number of } \\
\text { people to be } \\
\text { relocated close by in } \\
\text { higher quality } \\
\text { dwellings }\end{array}$ & $\begin{array}{l}\text { - Transit agency's } \\
\text { decision-making chan- } \\
\text { ged to focus on } \\
\text { matching low-income } \\
\text { areas to transit } \\
\text { technologies } \\
\text { - } 35 \text { new businesses } \\
\text { opened in the first } 3 \\
\text { months of Line K } \\
\text { - New technical } \\
\text { standards, laws and } \\
\text { regulations were } \\
\text { passed for } \\
\text { Metrocable's } \\
\text { implementation } \\
\text { (during project } \\
\text { execution) } \\
\text { - Local presence of } \\
\text { public and financial } \\
\text { institutions increased }\end{array}$ & $\begin{array}{l}\text { - Land values around } \\
\text { Line K stations } \\
\text { increased by } 50 \% \\
\text { immediately after } \\
\text { stations were } \\
\text { constructed } \\
\text { - Local business saw } \\
\text { increased footfall \& } \\
\text { revenue } \\
\text { - Integration with } \\
\text { metro reduced } \\
\text { travel costs by } 65 \% \\
\text { - Follow up } \\
\text { investments made } \\
\text { for four more } \\
\text { Metrocable lines }\end{array}$ & $\begin{array}{l}\text { - Street life and } \\
\text { use of } \\
\text { recreational, } \\
\text { cultural, } \\
\text { financial } \\
\text { resources } \\
\text { increased } \\
\text { - + 150,000 low } \\
\text { income } \\
\text { residents use } \\
\text { Metrocable } \\
\text { lines } \\
\text { - Above-average } \\
\text { decline in } \\
\text { homicide rate } \\
\text { around } \\
\text { stations } \\
\text { - Average } \\
\text { commutes } \\
\text { decreased } \\
\text { from } 90 \text { to } 30 \\
\text { min }\end{array}$ & $\begin{array}{l}\text { - Increased trust in } \\
\text { the justice } \\
\text { system } \\
\text { - Increased social } \\
\text { cohesion } \\
\text { - Positive outlook } \\
\text { relating to sense } \\
\text { of belonging to } \\
\text { the city, hope } \\
\text { and opportunity }\end{array}$ \\
\hline
\end{tabular}

their inclusion and integration into the city (Brand 2013), and the subsequent catalytic cycle of investing in participatory public projects in low-income areas. In an informal interview with the Supervisor of the Santo Domingo Metrocable station and a long-term resident, he describes the effect of the investments in his neighborhood:

"We never imagined that the company [Metro de Medellín] was dedicated and determined to really do the project. So, they started to socialize, to convince us, and to break the paradigms, and show that effectively it was going to be built. And more than just breaking the cultural paradigms, they managed, through the project, to integrate us into the city."

Physically, Metrocable eroded the spatial stigmatization of deprived and disconnected hillside neighborhoods, by connecting them to the city center and larger transit network, thereby redefining what constituted city boundaries (Brand 2013). In tandem investments in new public spaces and institutions around the transit infrastructure demonstrated the municipality's commitment to investing in the physical infrastructure of its informal areas, and the connection of formal utilities, such as electricity and water, indicated a new recognition of a community previously excluded from city government processes. In an informal interview with the General Manager of Metro de Medellín, he summarizes this investment and the subsequent effects:

"State investment in public spaces, facilities and social investment has increased in these areas, and this has generated a transformation, not only physical, but also in the way the people think." 
These multi-dimensional changes were significant to improving the quality of life in Medellín's informal areas, and it is the manner in which they were implemented that made them effective. The targeted outreach and partnerships with CBOs and transparent project execution and finance made the establishment of formalized infrastructures and processes within Santo Domingo a symbol of a positive and committed state presence. By building relationships with residents of its informal areas, the municipality was able to shift perceptions of what it means to belong to a place and be considered worthy of investment. In an informal interview with a social development worker from Metro de Medellín, he describes the effect of the community outreach:

"All the work that we did with the community created a shared responsibility, and when there is co-responsibility, people work together, we work hand in hand with the community, creating new spaces for the people."

This process of participatory public investments has become institutionalized in Medellín, with city agencies such as Metro de Medellín using the Metrocable experience as a blueprint for their ongoing investments in public space and transit infrastructure (Corburn et al. 2019). 'Social urbanism' has remained a popular urban development strategy across successive administrations since Line $\mathrm{K}$, though it has evolved and received criticism over the years, as some believe that it has failed to address the factors underlying socio-economic inequalities in informal areas (Maclean 2015).

The remarkable transformative impacts achieved by Line $\mathrm{K}$ have inspired other cities in Colombia and across Latin America to build their own Metrocable lines. While replicating the technology itself has proved relatively easy, the other Metrocables, including those in Medellín, have not had comparable success. Relative impact in these cases has been smaller, and arguably less transformative. Rather than completely reestablishing the presence of the state and formal institutions in places where they had been absent and creating a direct path of city-citizen communication, these subsequent investments have made more incremental adjustments. For instance, the cable car in Rio de Janeiro, established for the 2016 Olympics and designed to be a symbol of peace and prosperity for one of the city's most impoverished slums, is no longer running. Due to mismanaged finances and poor engagement during the project planning process, the cable car shut down only months after being inaugurated, despite having some initial benefits to residents in terms of reduced commute times and increased safety (Gaffney 2016).

Today, longer-term indicators of the citywide turnaround can be seen in the vastly decreased homicide rate, in particular in areas where spatial interventions have taken place (Cerda et al. 2012), which has removed Medellín from the top 50 most violent cities in the world. It can also be seen in the decrease in extreme poverty in the city, which has been reduced from 36\% of the population in 2002 to 3\% by 2015 (Corburn et al. 2019). In addition, there has been a continuous lack of municipal corruption and a relatively high level of transparency in Medellín, especially when compared to other Colombian cities (IDB 2011). While these indicators may not all be directly linked to the intervention in Santo Domingo or its institutionalized process of planning for large-scale projects, they are still indicative of a city undergoing a long-term, positive transformation. 


\section{Conclusion}

Our account of the case of Line $\mathrm{K}$ in Medellín draws attention to the importance of context, place, and long-term, multi-level factors of change in shaping the local trajectories of urban transformation. In this final section we reflect on the interaction between several elements that have shaped Line $\mathrm{K}$ into a transformative intervention for the city.

- National policy. Line K was catalyzed by devolution in the 1990s, which allowed the city government greater autonomy to access and understand the cultural and political nuances of its informal areas.

- Institutional learning. By drawing on lessons learned in the 1990s for how to conduct appropriate and informative community engagement, project teams from Metro de Medellín and the municipality were able to design an approach for Line $\mathrm{K}$ that overcame decades of distrust and resentment towards formal institutions.

- Strategic public finance. The municipality made strategic investments that demonstrated its capacity and dedication to work in informal areas by entering into a cost-sharing agreement with the partially-private transit agency, by leveraging increased tax revenue from the national government and by redirecting funds from Empresas Publicas de Medellín, the public utilities company. These decisions enabled the construction of Line $\mathrm{K}$ to be on-time and well-managed and demonstrated the municipality's readiness to fulfill its commitment to residents of Santo Domingo.

- Multi-sector partnerships. Building relationships with CBOs gave the municipality critical insights on how and where to structure its spatial investments, while partnerships with the private sector held the municipality accountable to local residents. United by a common desire to rewrite the violent narrative of Medellín and create a more unified and positive future for the city, the knowledge and skills exchanged in these partnerships allowed for more strategic project planning and the ability to capitalize on the institutional learning done in the 1990s.

Interactions between these elements gave way to a process that ultimately allowed for the city to begin investing in its informal, highly violent areas. The process of devolution, coupled with the mandate to form the Presidential Council of Medellín, ensured that the relevant stakeholders were drawn into the process of improving their city. This both lent the municipality crucial information about the landscape and social dynamics of an unknown space (Santo Domingo) and gave the CBOs a strong role in crafting what the future of their community would look like. Strong dedication from the business and local communities to reshape the future of Medellín was paralleled by the municipality's commitment to communication and transparency. Community engagement was thorough and drew upon knowledge of the local environment to create a tailored approach to working with the residents of Santo Domingo. The municipality's commitment was also a visual; due to the well-funded nature of the project, social engagement and construction workers were in the neighborhood every day and the cable car was able to be built without any delays in construction. Finally, the strategic partnership between Metro de Medellín and the municipality allowed for the two entities to exchange knowledge of best practices for community engagement as well as project finance and management, and strategically deploy staff to work in Santo Domingo. 
Overall, the municipality was able to develop a comprehensive strategy for Metrocable that capitalized on the city's municipal revenue collection and management strategies, deep-rooted community-based organizations, and multi-actor push for government transparency in order to establish a positive state presence in an area where it had been absent. While there are some elements unique to the Medellín case, such as the city's financial capacity and the targeted support it received from the national government, the enduring success of the intervention - which is now over a decade old - indicates the need to further consider how these elements can be used in other contexts and how the barriers to their establishment may be mitigated.

\section{Abbreviations \\ CBO: Community-based organization; PRIMED: Integrated Slum Upgrading Program of Medellín (Programa Integral de Mejoramiento de Barrios Subnormales en Medellín); PUI: Integral Urban Project (Proyecto Urbano Integral)}

\section{Acknowledgements}

The authors declare that they were the only ones involved in the production of this work.

\section{Authors' contributions}

Both authors contributed to the production of this manuscript, with M.G. taking the lead. Both authors have read and approved the final version.

\section{Funding}

This research is based off a project funded by Stephen M. Ross Philanthropies. There was no additional funding for this research.

\section{Availability of data and materials}

There were no datasets used or produced in this research.

\section{Competing interests}

The authors declare they have no competing interests.

Received: 2 April 2019 Accepted: 6 May 2020

Published online: 15 May 2020

\section{References}

Bahl V. Murder capital to modern miracle? The progression of governance in Medellín, Colombia. London: University College London; 2012. https://assets.publishing.service.gov.uk/media/57a08a9eed915d3cfd00085a/60726_Bahl_murder.pdf.

Bateman M, Ortiz JPD, Maclean K. A post-Washington consensus approach to local economic development in Latin America? An example from Medellín, Colombia. London: Overseas Development Institute; 2011. https://www.odi.org/sites/odi.org. uk/files/odi-assets/publications-opinion-files/7054.pdf.

Bocarejo J, Portilla I, Velasquez J, Cruz M, Pena A, Oviedo D. An innovative transit system and its impact on low income users: the case of the Metrocable in Medellín. Journal of Transport Geography. 2014;39:49-61 https://doi.org/10.1016/j.jtrangeo. 2014.06.018.

Brand P. Governing inequality in the south the Barcelona model: 'social urbanism' in Medellín, Colombia. Leicester: Paper presented at interrogating urban crisis conference; 2013.

Brand, P, Dávila, J. Mobility innovation at the urban margins. City. 2011;15:647-661. https://doi.org/10.1080/13604813.2011. 609007.

Cerda M, Morenoff J, Hansen B, Hicks K, Duque L, Restrepo A, Diez-Roux A. Reducing violence by transforming neighborhoods: a natural experiment in Medellín, Colombia. Am J Epidemiol. 2012;175:1045-53. https://doi.org/10.1093/ aje/kwr428.

Corburn J, Asari MR, Jamarillo JP, Gaviria A. The transformation of Medellín into a 'City of life:' insights for healthy cities. Cities \& Health. 2019. https://doi.org/10.1080/23748834.2019.1592735.

Ferrari SG, Smith H, Coupe F, Rivera H. City profile: Medellín. Cities. 2018;74:354-64. https://doi.org/10.1016/j.cities.2017.12.011.

Franz T. Urban governance and economic development in Medellín. Lat Am Perspect. 2017;44:52-70. https://doi.org/10.1177/ $0094582 \times 16668313$.

Gaffney C. Transforming Rio - for the benefit of whom? Journal of sport science and physical education. 2016;70. https://doi. org/10.5167/uzh-132366.

Gomez R, Olivera M, Velasco MA. Implementing a subnational results-oriented management and budgeting system: Lessons from Medellín, Colombia. Washington, DC: The World Bank; 2009. http://hdl.handle.net/10986/28072.

IDB. Medellín: trasformación de una ciudad. Medellín: IDB; 2011.

Maassen A, Galvin M. What does urban transformation look like? Findings from a global prize competition. Sustainability. 2019;17:4653. https://doi.org/10.3390/su11174653.

Maclean K. Social urbanism and the politics of violence: the Medellín miracle. Basingstoke: Palgrave Macmillan; 2015.

Moncada E. Cities, business and the politics of urban violence in Latin America. Stanford: Stanford University Press; 2016a. p. $55-87$.

Moncada E. Urban violence, political economy and territorial control: insights from Medellín. Latin America Research Review. 2016b;51:225-48. https://doi.org/10.1353/lar.2016.0057. 
Ramirez RM. Metrocable: an axis of development for the Valle de Aburrá. Medellín: Revista Metro; 2011.

Restreppo EA, Orsini FM. Informality and social urbanism in Medellín. In: Medellín: environment, urbanism, society. Medellín: Urbam; 2015. p. 132-56. https://www.umass.edu/larp/sites/default/files/AE\%20FM\%20Informality\%20and\%20Social\%2 OUrbanism\%20in\%20Medelli\%C2\%A6\%C3\%BCn.pdf.

Restreppo-Miethe A. Divided we fall: grassroots, business elites, and the pursuit of progressive planning institutionalization in Medellín, Colombia. Portland: Paper presented at the 56th annual ACSP conference; 2016.

Salazar N. The political economy of tax reforms: the case of Colombia. Washington, DC: Wilson Center Latin America Program; 2013. https://www.wilsoncenter.org/sites/default/files/SalazarTaxReformColombia.pdf.

Sotomayor L. Equitable planning through territories of exception: the contours of Medellín's urban development projects. Int Dev Plan Rev. 2015;37:373-97. https://doi.org/10.3828/idpr.2015.23.

\section{Publisher's Note}

Springer Nature remains neutral with regard to jurisdictional claims in published maps and institutional affiliations.

Ready to submit your research? Choose BMC and benefit from:

- fast, convenient online submission

- thorough peer review by experienced researchers in your field

- rapid publication on acceptance

- support for research data, including large and complex data types

- gold Open Access which fosters wider collaboration and increased citations

- maximum visibility for your research: over $100 \mathrm{M}$ website views per year

At $B M C$, research is always in progress. 